\section{The WTO and the regulation of international trade: Recent trade disputes between European Union and the United States}

Nicolas Pirdikis and Robert Read (eds)

Reviewed by

Rakesh Kacker

Advisor, B\&CS Department

Telecom Regulatory Authority of India, New Delhi

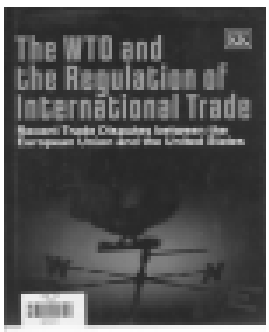

Hardbound

295 pp. 2005

ISBN 1843762005

International Journal of Regulation and Governance 5(2): 143-146

The book tries to analyse efficacy of the new dispute-settlement mechanism under the WTO (World Trade Organization) that came into force in 1995 consequent to the Uruguay Round Negotiations. This it has done through the lens of disputes between the EU (European Union) and the US. And accordingly, the book is subtitled Recent trade disputes between European Union and the United States. The rationale for focusing upon the trade disputes between the EU and the US is that they are responsible for almost $60 \%$ of the international trade and $40 \%$ of the trade dispute cases after the inception of the WTO.

The book can be divided into two broad parts. The first deals with generic issues of political economy of protection and the nature of trade dispute settlement mechanism under the WTO as well as some analysis of the genesis of trade conflicts between the EU and the US. The second part of the book deals with specific cases of the Banana Trade Dispute, the Steel Dispute, Export Tax Credits of the US, the Beef Hormones Case, and potential dispute in trade in genetically modified goods. The book finally winds up with a few conclusions on the dispute-settlement mechanism in light of these disputes.

The scope of the book is clearly limited as it explicitly focuses on disputes between the US and the EU. There is a passing reference to problems of the developing countries: constraints of financial and intellectual resources required to fight dispute settlement cases. Details of the individual cases show that when 
one of the parties is not willing to cooperate, effective remedies can still take years to come about. Through these years, there has to be persistent follow-up and constant pressure on ensuring that the rules laid down are enforced. Quite clearly, even tough the WTO DSU (dispute settlement understanding) is an improvement over the GATT (General Agreement on Trade and Tariff) procedure, the ability of weaker countries to be able to get full benefit of the WTO rule-based system is still very much in doubt. It would be interesting if this idea could have been developed further but perhaps, this could form the subject matter of a book by itself.

Given the scope of the book, it is a useful collection of papers, which sets out the basic rules and procedures governing the DSU of the WTO. The paper by Robert Read gives a comprehensive analysis of improvement of the WTO over the previous GATT dispute-settlement system, especially in terms of the negative consensus rule. The subsequent papers give an interesting analysis of the WTO DSU in contrast to the trade dispute mechanism of NAFTA (North American Free Trade Agreement). NAFTA provides flexibility to the initiating party to opt for either the NAFTA procedure or the WTO procedure. It remains to be seen whether over time, Canada and Mexico will use the WTO procedure while the US will remain with the NAFTA procedure. The role of the Common Agricultural Policy of the EU in provoking trade disputes with the US has been analysed at length. Not surprisingly, agriculture related issues have dominated trade disputes between the US and the EU under the WTO DSU.

The Banana Trade Dispute is unique in that the US intervened although the dispute was not about the export of bananas from the US but on grounds that the EU policy was adversely impacting the American firms. The other interesting observation is how the WTO DSU could come to a quick decision in contrast to the earlier disputes under GATT as the EU had vetoed those parts of the findings of GATT panel that were not favourable to its own interests. The other major agriculturebased dispute was the Beef Hormones Case where the EU regulation on beef hormones was challenged by the US. Despite an adverse finding by the WTO panel and its confirmation by the appellate body, the EU indicated that it would not comply with the ruling and this led to retaliation by Canada and the US. This 
led to further issues regarding the role of Carouseling. More importantly, this case showed the weakness of the DSU when a member chooses not to implement a panel ruling. Compensation gets ruled out in such a case and the only option left is retaliation when even countries as strong as the US are not able to use this effectively, prospects for weaker economies are quite clearly even more dim.

The other important agriculture-based case is the potential conflict in the trade in genetically modified goods where the US is again likely to challenge the EU regulation for genetically modified goods. Here, the dispute is going to focus on the precautionary principle (already raised in the beef hormone case and it remains to be seen how this dispute unfolds-this again has important consequences for the developing countries because a wide application of this principle could have considerable adverse consequences for them.

The case concerning US Export Tax Credits brings out the extent to which domestic sovereignty has to give way to a multilateral trading system. The US in this case, had amended the US Extra Territorial Income Act to comply with the earlier ruling. However, the EU did not accept this and the WTO upheld the EU's request. The steel dispute once again went against the US as it failed to demonstrate the sufficient justification for its action. This case demonstrated the power of the new system as it forced the US to move its domestic policies to bring them in conformity with its WTO obligations.

The over-whelming conclusion from the theoretical as well as detailed exposition of individual cases is that the WTO DSU is definitely an improvement over the old GATT system. Nevertheless, there are issues regarding enforcement of panel decision and the extent to which retaliatory action can be taken in case of non-compliance. The other major issue is the time taken to resolve a dispute in its entirety. A modification of policies consequent to the panel decision may not satisfy the complainant and can lead to another round of disputes. This open-ended nature of the WTO DSU is certainly a cause for concern for the developing countries, which have limited resources and capacity to engage the developed countries in these costly and timeconsuming processes.

This book provides a valuable collection of theoretical issues as well as a wealth of details on most important cases. These can 
be used to analyse the effectiveness of the DSU and also provide the base for further work on understanding how the DSU has worked in practice, its shortcomings, and how these can be overcome in future, especially for the developing countries whose powers of retaliation are much lower than the EU and the US. 